\title{
Distribution and population structure of the rockfish Helicolenus dactylopterus (Pisces: Scorpaenidae) in the western Mediterranean
}

\author{
Enric Massutí*, Joan Moranta ${ }^{\dagger}$, L. Gil de Sola ${ }^{\ddagger}$, B. Morales-Nin ${ }^{\dagger}$ and Llucia Prats ${ }^{\ddagger}$ \\ *IEO-Centre Oceanogràfic de les Balears, P.O. Box 291, 07080 Palma de Mallorca, Spain. E-mail: enric.massuti@ba.ieo.es \\ ${ }^{\dagger}$ CSIC/UIB-Institut Mediterrani d’Estudis Avançats, Miguel Marques 21, 07190 Esporles, Mallorca, Spain. \\ E-mail: ieajmm@clust.uib.es. ${ }^{\ddagger}$ IEO-Centro Oceanográfico de Málaga, PO Box 285, 29640 Fuengirola, Spain. \\ E-mail: gildesola@ma.ieo.es
}

\begin{abstract}
The distribution and spatio-temporal variation of Helicolenus dactylopterus (Pisces: Scorpaenidae) population was studied from 816 bottom trawls developed along the Iberian coast. Multifactor analysis of variance was used to test the differences in abundance and biomass and cluster analysis was applied to detect differences in population structure. The results showed a bathymetric and latitudinal gradient in abundance and population structure along three geographic sectors in the surveyed area. In the southern area, the species was more frequent and showed a wider bathymetric distribution range than northwards. The depth range with the maximum frequency of occurrence was also wider in the southern area than northwards. Similar trends were observed in terms of abundance and biomass, with the highest and lowest indices in the southern and northern areas, respectively. The age composition of the catches showed that the population consisted mainly of young-of-the-year and juvenile fish. This fraction of the population is well represented, at a mesoscale, along the whole surveyed area, but adults are well represented only at a local scale, at the deepest strata surveyed in the southern area. In this case, recruits of age 0 and juveniles up to 4 -y old were restricted to depths shallower than $500 \mathrm{~m}$, while adult fish older than $6 \mathrm{y}$ of age appeared below this depth. In the southern area, seasonal changes in the population structure were also observed, with modes of small fish $(3-6 \mathrm{~cm})$ from March to June, as a consequence of the species recruitment to the bottom. Some direct and indirect factors of biogeographic, environmental and anthropogenic origin affecting the observed gradient are discussed.
\end{abstract}

\section{INTRODUCTION}

Abundance and size structure are relevant topics to be analysed in the study of fish populations, and some determinant factors of these parameters must be taken into account. At a local scale, depth has been identified as one of the factors which determine size of demersal fish (e.g. Macpherson \& Duarte, 1991). In the same way, the influence of other factors such as density, hydrographic conditions, productivity, seasonality and fishing pressure has also been considered (e.g. Gordoa \& Duarte, 1992; Macpherson \& Gordoa, 1996). At a global scale, latitude must be also considered, because it plays an important role in the distribution of marine animals along the whole geographic range of the species (Macpherson \& Duarte, 1994).

The rockfish Helicolenus dactylopterus (Delaroche, 1809) (Pisces: Scorpaenidae) is a wide-spread species in the eastern Atlantic Ocean and in the Mediterranean Sea, where it plays an important ecological role in deep-sea fish communities (e.g. Stefanescu et al., 1994; Gordon et al., 1996). The biology of this species has been widely studied (e.g. Boutière, 1958; Macpherson, 1979; White et al., 1998; Muñoz et al., 1999; Massutí et al., 2000). Its bathymetric distribution and population structure has been studied in waters off Portugal (Cardador \& Pestana, 1995; Figueiredo et al., 1995),
Rockall Trough (Kelly et al., 1999), the North Sea (Heesen et al., 1996) and the Mediterranean Sea (e.g. D’Onghia et al., 1992).

The present paper integrates data from 21 surveys covering the whole Iberian Mediterranean coast, to analyse on a broad spatial scale the distribution and spatio-temporal variation of the $H$. dactylopterus population in this area. Data on abundance, length-frequency distribution, sex-ratio and age-length keys on this species are analysed, and the factors affecting these parameters are discussed.

\section{MATERIALS AND METHODS}

Data and samples were collected from 816 bottom trawls from 21 cruises carried out along the whole Iberian Mediterranean coast (between Punta Europa and Cape Creus; Figure 1). In each trawl, fresh weight in grams and number of Helicolenus dactylopterus were recorded, and the total length of a subsample was measured to the nearestcm. In addition, the sex was determined by macroscopic examination of the gonads and the sagittal otoliths were extracted from random subsamples collected to cover the whole size range of the species. Although the sampling procedure was the same in all surveys, data and samples of each one has been used for different purposes 


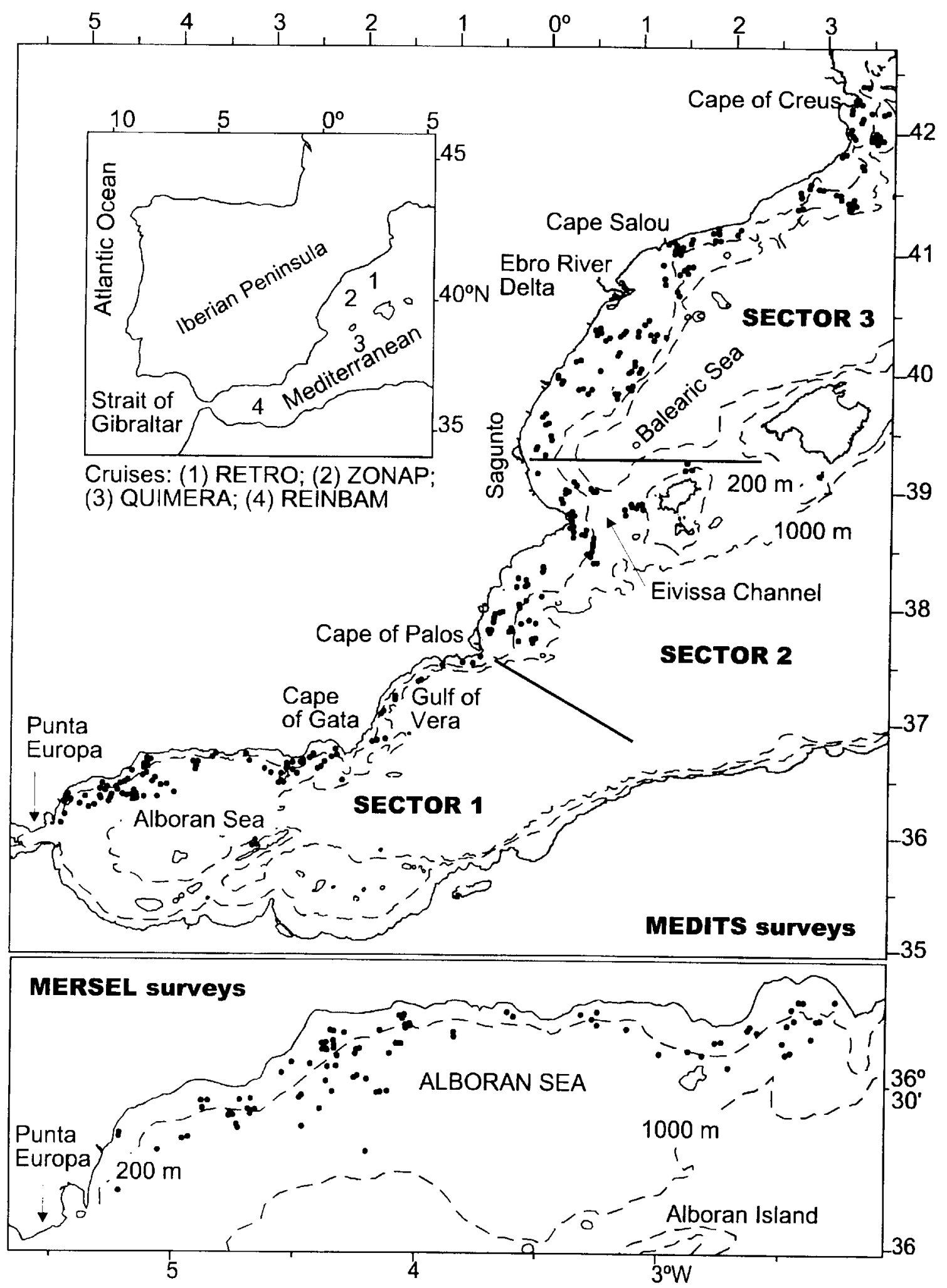

Figure 1. Western Mediterranean, showing area sampled during research cruises used in this study for Helicolenus dactylopterus catch data and biological sampling collection purposes (see Table 1). The sectors established on the MEDITS programme along the prospected area, and the location of hauls during the MEDITS and MERSEL surveys are also shown.

(Table 1) to reduce bias caused by different trawl gears used (Table 2).

Abundance and biomass were analysed only from data obtained in MEDITS surveys. According to the MEDITS programme (Bertrand et al., 1998), three geographic sectors were determined: (i) sector 1 from Punta Europa to Cape Palos (Alboran sea); (ii) sector 2 from Cape Palos to Sagunto (an area much influenced by the Eivissa Channel); and sector 3 from Sagunto to Cape Creus (Balearic Sea). In each sector, five depth intervals 
Table 1. Sampling cruises (date, depth range surveyed, number of hauls and trawl gear used) and sample collections (catch data in number and weight, specimens measured and otolith sampling) of Helicolenus dactylopterus analysed.

\begin{tabular}{|c|c|c|c|c|c|c|c|c|}
\hline Survey & Date & Depth $(\mathrm{m})$ & Hauls & Gear & Number & Grams & Length & Otoliths \\
\hline MD0694 & $28 / 05-14 / 06 / 94$ & $27-786$ & 78 & GOC73 & 596 & 29201 & 559 & 315 \\
\hline MD0595 & $22 / 04-21 / 05 / 95$ & $25-771$ & 106 & GOC73 & 1092 & 29928 & 841 & 491 \\
\hline MD0596 & $02 / 05-26 / 05 / 96$ & $27-795$ & 106 & GOC73 & 2503 & 94401 & 1180 & 875 \\
\hline MD0597 & $10 / 05-03 / 06 / 97$ & $27-761$ & 101 & GOC73 & 1369 & 70848 & 697 & 851 \\
\hline Total & & & 391 & & 5560 & 224378 & & \\
\hline ML0691 & $05 / 06-17 / 06 / 91$ & $45-499$ & 29 & Baka & & & 1106 & 0 \\
\hline ML1091 & $16 / 10-30 / 10 / 91$ & $46-500$ & 37 & Baka & & & 887 & 0 \\
\hline ML0392 & $15 / 03-05 / 04 / 92$ & $58-499$ & 23 & Baka & & & 403 & 0 \\
\hline ML0992 & $11 / 09-01 / 10 / 92$ & $40-499$ & 40 & Baka & & & 571 & 0 \\
\hline ML0693 & $22 / 06-03 / 07 / 93$ & $39-500$ & 34 & Baka & & & 302 & 0 \\
\hline ML1193 & $27 / 11-08 / 12 / 93$ & $40-618$ & 22 & Baka & & & 278 & 203 \\
\hline ML1094 & $05 / 10-15 / 10 / 94$ & $45-412$ & 22 & Baka \& GOC73 & & & 423 & 0 \\
\hline ML1095 & $16 / 10-28 / 10 / 95$ & $42-714$ & 34 & Baka & & & 630 & 200 \\
\hline ML1096 & $15 / 10-29 / 10 / 96$ & $36-790$ & 36 & Baka & & & 468 & 44 \\
\hline ML1097 & $7 / 10-23 / 10 / 97$ & $47-696$ & 35 & Baka & & & 673 & 0 \\
\hline Total & & & & & & & 9018 & \\
\hline RI & $23 / 04-26 / 04 / 91$ & $378-1258$ & 9 & OTMS-27.5 & & & & 92 \\
\hline RII & $07 / 12-10 / 12 / 91$ & $433-1273$ & 9 & OTMS-27.5 & & & & 15 \\
\hline RIII & $12 / 03-13 / 03 / 92$ & $355-1276$ & 9 & OTMS-27.5 & & & & 35 \\
\hline Z0592 & $22 / 05-30 / 05 / 92$ & $202-1150$ & 38 & OTSB-14 & & & & 95 \\
\hline RIV & $26 / 07-28 / 07 / 92$ & $434-1293$ & 9 & OTMS-27.5 & & & & 46 \\
\hline QI & $17 / 10-24 / 10 / 96$ & $241-1713$ & 31 & OTMS-27.5 & & & & 100 \\
\hline RB0297 & $11 / 02-15 / 02 / 97$ & $385-770$ & 8 & Baka Cornide & & & & 31 \\
\hline Total & & & & & & & & 3393 \\
\hline
\end{tabular}

Surveys: MD, MEDITS; ML, MERSEL; R, RETRO; Z, ZONAP; Q QUIMERA; RB, REINBAM.

Table 2. Mean characteristics of the different bottom trawl gears used and references including their comprehensive description. The effective opening and towing speed were measured using a SCANMAR system.

\begin{tabular}{|c|c|c|c|c|c|}
\hline \multirow[b]{2}{*}{ Trawl gear } & \multicolumn{2}{|c|}{ Opening $(\mathrm{m})$} & \multirow{2}{*}{$\begin{array}{c}\text { Codend } \\
\text { Mesh size (mm) }\end{array}$} & \multirow{2}{*}{$\begin{array}{c}\text { Towing speed } \\
\text { (Knots) }\end{array}$} & \multirow[b]{2}{*}{ References } \\
\hline & Horizontal & Vertical & & & \\
\hline GOC73 & 16.4 & 2.8 & 20 & 2.8 & Betrand et al. (1998) \\
\hline Baka & 19.7 & 1.9 & 20 & 2.7 & Gil de Sola (1994) \\
\hline OTMS-27.5 & 14.0 & $1.8-2.0$ & 12 & 2.5 & Sardà et al. (1998) \\
\hline OTSB-14 & 6.7 & $1.5-2.0$ & 12 & 2.5 & Merret \& Marshall (1981) \\
\hline Baka Cornide & 22.0 & 1.9 & 20 & 3.0 & Sánchez (1993) \\
\hline
\end{tabular}

were examined: (i) $10-50 \mathrm{~m}$ (stratum A); (ii) $51-100 \mathrm{~m}$ (stratum B); (iii) 101-200 m (stratum C); 201-500 m (stratum D); and (v) 501-800 m (stratum E). The indices of abundance and biomass were computed as stratified mean and variance for each sector and strata, following the standard procedures of the MEDITS programme. Annual, bathymetric and geographic differences were also examined by frequency of occurrence, calculated as number of hauls in which the species appeared in relation to total number of hauls analysed by year, sector and depth strata.
The spatial and temporal variation on the population demography was also calculated only from MEDITS surveys, using the length-frequency distribution by sector, depth-strata and year, the age-length key by sector and the sex composition by length for the whole studied period. Due to the longevity of the species, an age-class $15+$ was grouped. Methodology used for age determination is explained in Massutí et al. (2000). The seasonal variation (spring and autumn) in the population structure was analysed in the 
Alboran Sea, from length-frequency distributions obtained on each MERSEL survey and from sector 1 of MEDITS surveys.

Multifactor analysis of variance was used to test the null hypothesis: fish abundance and biomass were the same among years, sectors and strata. The multiple range Student-Newman-Keuls test was applied to determine which means were significantly different from others. Before analysis the assumptions of normality of data and homogeneity of variance were tested using the Kolmogorov-Smirnov and Cochran's test respectively. When these assumptions were not met data were transformed by $\ln (\mathrm{x}+1)$, and then the assumptions were tested again.

Cluster analysis based on the resemblance between age composition by year, sector and strata (only samples $\geqslant 15$ fish were considered) was applied to analyse differences in population structure. The Czekanowski's percentage similarity index and the UPGMA were used as the similarity index and as the aggregation algorithm, respectively. Czekanowski's percentage similarity index is a measure of the intersection surface in relation to the reunion surface of two equal area-frequency distributions. LAWI software (J. Lleonart, CSIC, unpublished data) was used to perform the analysis. This method was also used to test seasonal variation in population structure. For this purpose, length-frequency distributions obtained in the Alboran Sea at different seasons were compared.

\section{RESULTS}

From the analysis of MEDITS cruises, Helicolenus dactylopterus was always more frequent and abundant in sector 1, while sector 3 showed the lowest frequency of occurrence and abundance and biomass values (Figure 2). Significant differences were found between sectors and strata for both abundance and biomass, but without significant interannual variations (Table 3). The widest bathymetric range was obtained in sector 1 (Figure 3), where the species appeared between 51 and $800 \mathrm{~m}$ depth, with higher values of frequency of occurrence $(>70 \%)$ at $\mathrm{C}-\mathrm{E}$ depth-strata. In sectors 2 and 3, the species appeared below $100 \mathrm{~m}$ depth and the highest values of frequency of occurrence $(>80 \%)$ were obtained at depth-strata $\mathrm{C}-\mathrm{D}$ and $\mathrm{D}$, respectively. The highest abundance and biomass were also obtained in sector 1 (Figure 3), with values of $>540$ fish $\mathrm{km}^{-2}$ and $>12 \mathrm{~kg} \mathrm{~km}^{-2}$ at $\mathrm{C}-\mathrm{D}$ and $\mathrm{C}-\mathrm{E}$ depth-strata, respectively. In sector 2 the highest values of abundance and biomass were obtained at $\mathrm{C}-\mathrm{D}$ depth-strata $(\sim 400$ fish $\mathrm{km}^{-2}$ and $5.5 \mathrm{~kg} \mathrm{~km}^{-2}$ ) and in sector 3 the highest abundance was obtained also at $\mathrm{C}-\mathrm{D}$ depth-strata $(\sim 200$ fish $\mathrm{km}^{-2}$, while the highest biomass only at depth-stratum $\mathrm{D}\left(8 \mathrm{~kg} \mathrm{~km}^{-2}\right)$.

The percentage of sexes in each length-class is shown in Figure 4. The sex of any fish $<7 \mathrm{~cm}$ could not be determined, and a high percentage $(>50 \%)$ of fish $\leqslant 10 \mathrm{~cm}$ could not be sexed. For sizes $>18 \mathrm{~cm}$, all fish were sexually differentiated. Both females and males were equally represented between 8 and $16 \mathrm{~cm}$ and at $24-25 \mathrm{~cm}$ $\left(\chi^{2}\right.$-test, $\left.P>0.05\right)$, while females predominated from 17 and $23 \mathrm{~cm}$ and males predominated in fish $\geqslant 26 \mathrm{~cm}$ $\left(\chi^{2}\right.$-test, $\left.P<0.05\right)$.
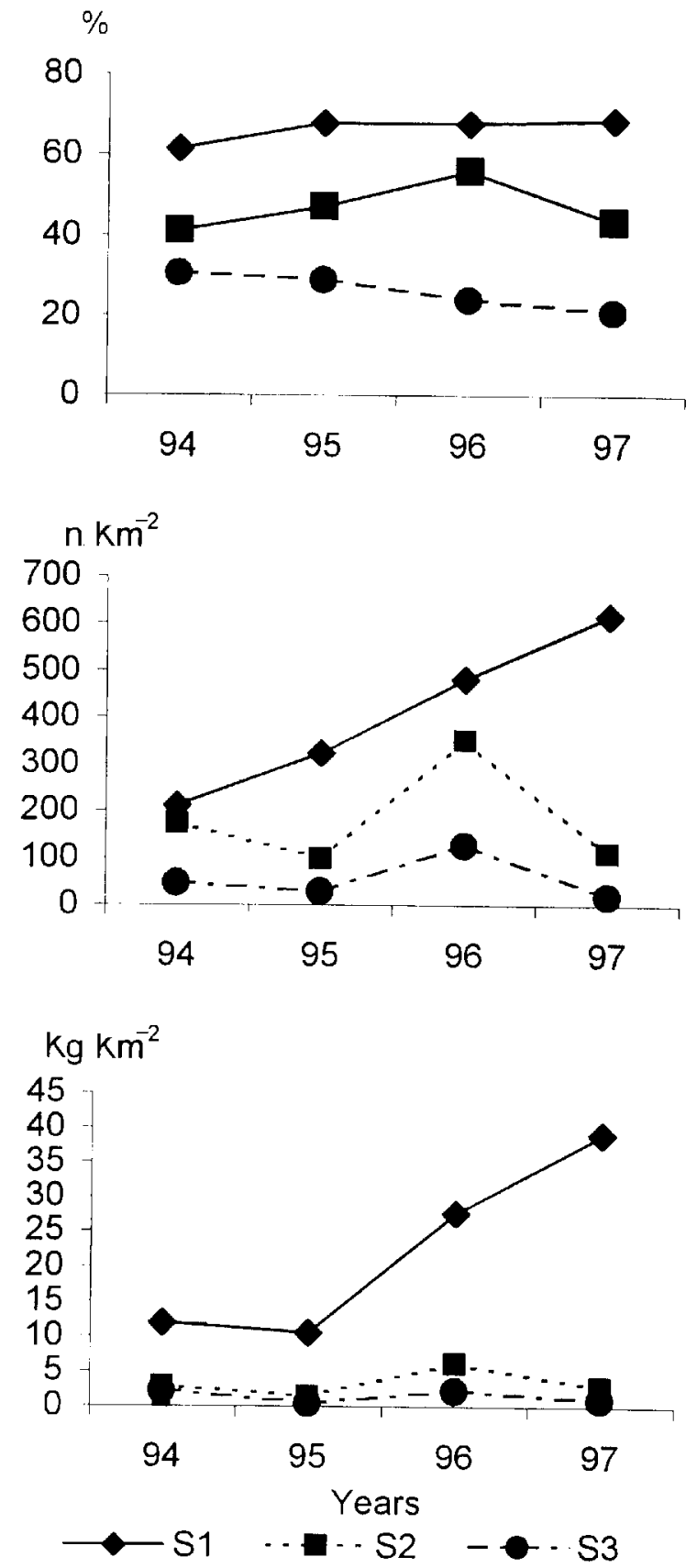

Figure 2. Frequency of appearance (\%) and indices of relative abundance $\left(\mathrm{N} \mathrm{km}^{-2}\right)$ and biomass $\left(\mathrm{kg} \mathrm{km}^{-2}\right)$ of Helicolenus dactylopterus obtained by sector and year during the MEDITS surveys.

A total of 3393 otoliths were observed, of which 11\% were considered uninterpretable. The age-length keys by sector (Table 4) showed that in sector 1 fish between $3-36 \mathrm{~cm}$ ranged from 0 to $30 \mathrm{y}$, in sector 2 fish between 2 and $23 \mathrm{~cm}$ ranged from 0 to $10 \mathrm{y}$ old and in sector 3 fish between 3 and $30 \mathrm{~cm}$ ranged from 0 to $22 \mathrm{y}$.

In all sectors, the most frequent ages were 0,1 and 2, found in depth-strata $\mathrm{C}$ and D (Figure 5). In depthstrata $\mathrm{E}$ there was a dominance of older fish, with no clear modal age composition pattern. The dendrogram of similarities obtained from the age composition allowed the identification of several groups (Figure 6). The first 
Table 3. Summary of the statistics analysis to test the difference in fish abundance and biomass [both $\ln (x+1)$ transformed] between years (1994, 1995, 1996 and 1997), sectors (S1, S2 and S3, see Figure 1) and stratum (C, 100-200 m; D, 200-500 m; E, $500-800 \mathrm{~m})$. Data comes from a normal distribution. The non-significant 1st-or 2nd-order interaction were eliminated from the model for the analysis.

(A) Test for homogeneity of variance Cochran's test.

$\begin{array}{ll}\text { Abundance: } & 0.081(P=0.3) \\ \text { Biomass: } & 0.065(P=1.0)\end{array}$

(B) Multifactor analysis of variance for abundance $(\mathcal{N})$ and biomass $(\mathrm{kg})$.

SS

$\mathrm{N} \quad \mathrm{kg} \quad \mathrm{df}$

Main effects

Year

Sector $(\mathrm{S})$

Depth-Strata (D-S)

Interactions

$\mathrm{S} \times \mathrm{D}-\mathrm{S}$

Residual

Total

$\begin{array}{rrr}16.6 & 33.9 & 3 \\ 98.3 & 393.1 & 2 \\ 103.6 & 139.2 & 2 \\ & & \\ 41.5 & 160.1 & 4 \\ 497.6 & 1698.6 & 226 \\ 708.0 & 2418.3 & 237\end{array}$

(C) Multiple range test Student-Newman-Keuls (SNK) test for abundance.

Effect of abundance at each sector

\begin{tabular}{|c|c|c|c|c|c|c|c|c|c|}
\hline \multirow[b]{2}{*}{ Depth-strata } & \multicolumn{3}{|c|}{ Mean abundance at S1 } & \multicolumn{3}{|c|}{ Mean abundance at S2 } & \multicolumn{3}{|c|}{ Mean abundance at S3 } \\
\hline & $\mathrm{C}$ & $\mathrm{D}$ & $\mathrm{E}$ & C & $\mathrm{D}$ & $\mathrm{E}$ & $\mathrm{C}$ & $\mathrm{D}$ & $\mathrm{E}$ \\
\hline Mean & 4.0 & 2.6 & 1.8 & 2.5 & 2.3 & 0.4 & 1.1 & 1.9 & 0.6 \\
\hline \multirow[t]{2}{*}{ Difference } & ${ }^{\mathrm{E}-\mathrm{C}} 1.4^{*}$ & E-D $0.7 *$ & & ${ }^{\mathrm{E}-\mathrm{C}_{2}} 2.1 *$ & E-D $1.8 *$ & & E-C 0.5 & $\mathrm{E}-\mathrm{D} 1.3 *$ & \\
\hline & D-C $2.2 *$ & & & $\mathrm{D}-\mathrm{C}_{0.2}$ & & & ${ }^{\mathrm{D}-\mathrm{C}}-0.8^{*}$ & & \\
\hline
\end{tabular}

Effect of abundance at each depth-strata

\begin{tabular}{|c|c|c|c|c|c|c|c|c|c|}
\hline \multirow{4}{*}{$\begin{array}{l}\text { Sector } \\
\text { Mean } \\
\text { Difference }\end{array}$} & \multicolumn{3}{|c|}{ Mean abundance at $\mathrm{C}$} & \multicolumn{3}{|c|}{ Mean abundance at D } & \multicolumn{3}{|c|}{ Mean abundance at $\mathrm{E}$} \\
\hline & 1 & 2 & 3 & 1 & 2 & 3 & 1 & 2 & 3 \\
\hline & 4.0 & 2.5 & 1.1 & 2.6 & 2.3 & 1.9 & 1.8 & 0.4 & 0.6 \\
\hline & ${ }^{3-1} 2.9 *$ & ${ }^{3-2} 1.4 *$ & & ${ }^{3-1} 0.7$ & ${ }^{3-2} 0.4$ & & ${ }^{3-1} 1.2 *$ & ${ }^{3-2}-0.1$ & \\
\hline & ${ }^{2-1} 1.5 *$ & & & ${ }^{2-1} 0.3$ & & & ${ }^{2-1} 1.4 *$ & & \\
\hline
\end{tabular}

(D) Multiple range SNK test for biomass.

Effect of abundance at each sector

\begin{tabular}{|c|c|c|c|c|c|c|c|c|c|}
\hline \multirow[b]{2}{*}{ Depth-strata } & \multicolumn{3}{|c|}{ Mean biomass at $\mathrm{S} 1$} & \multicolumn{3}{|c|}{ Mean biomass at $\mathrm{S} 2$} & \multicolumn{3}{|c|}{ Mean biomass at $\mathrm{S} 3$} \\
\hline & $\mathrm{C}$ & $\mathrm{D}$ & $\mathrm{E}$ & $\mathrm{C}$ & $\mathrm{D}$ & $\mathrm{E}$ & $\mathrm{C}$ & $\mathrm{D}$ & $\mathrm{E}$ \\
\hline Mean & 6.4 & 5.3 & 5.5 & 4.4 & 4.6 & 1.5 & 1.7 & 4.3 & 1.7 \\
\hline Difference & ${ }^{\mathrm{E}-\mathrm{C}_{0}} 0.9$ & $\mathrm{E}-\mathrm{D}-0.2$ & & $\mathrm{E}-\mathrm{C}_{2.9}$. & ${ }^{\mathrm{E}-\mathrm{D}} 3.1 *$ & & ${ }^{\mathrm{E}-\mathrm{C}} 0.1$ & E-D2.6* & \\
\hline & ${ }^{\mathrm{D}-\mathrm{C}} 1.1$ & & & $\mathrm{D}-\mathrm{C} 0.2$ & & & $\mathrm{D}-\mathrm{C}-2.6^{*}$ & & \\
\hline
\end{tabular}

Effect of abundance at each depth-strata

\begin{tabular}{|c|c|c|c|c|c|c|c|c|c|}
\hline \multirow{4}{*}{$\begin{array}{l}\text { Sector } \\
\text { Mean } \\
\text { Difference }\end{array}$} & \multicolumn{3}{|c|}{ Mean biomass at $\mathrm{C}$} & \multicolumn{3}{|c|}{ Mean biomass at $\mathrm{D}$} & \multicolumn{3}{|c|}{ Mean biomass at $\mathrm{E}$} \\
\hline & 1 & 2 & 3 & 1 & 2 & 3 & 1 & 2 & 3 \\
\hline & 6.4 & 4.4 & 1.7 & 2.6 & 2.3 & 1.9 & 5.5 & 1.5 & 1.7 \\
\hline & ${ }^{3-1} 4.7 *$ & $3-22.7 *$ & & ${ }^{3-1} 1.1$ & ${ }^{3-2} 0.3$ & & ${ }^{3-1} 3.8 *$ & ${ }^{3-2}-0.2$ & \\
\hline & ${ }^{2-1} 2.0$ * & & & ${ }^{2-1} 0.8$ & & & ${ }^{2-1} 4.0 *$ & & \\
\hline
\end{tabular}

\footnotetext{
*, denotes a statistically significant difference at the $95 \%$ confidence level.
} 

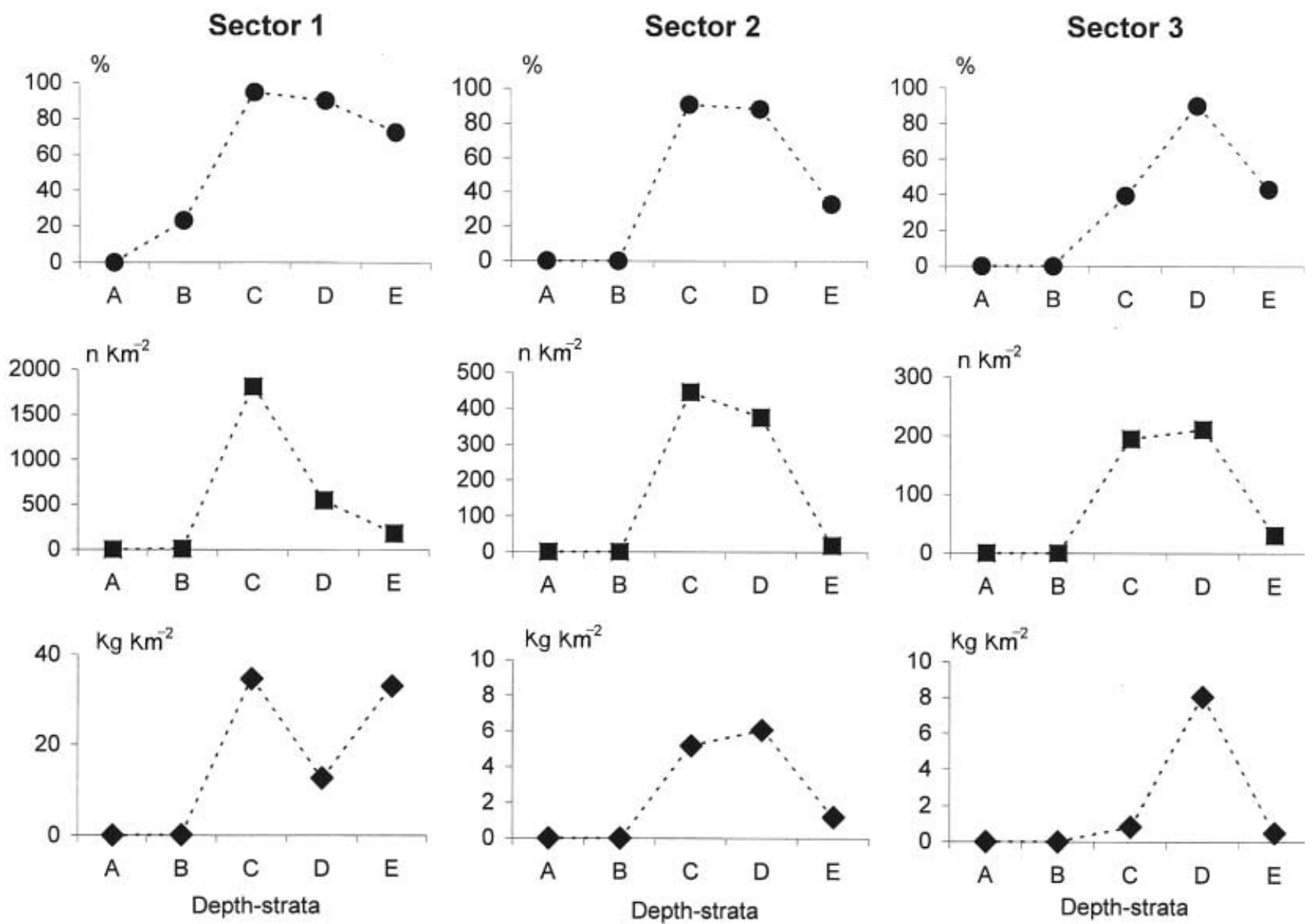

Figure 3. Frequency of appearance (\%) and indices of relative abundance $\left(\mathrm{N} \mathrm{km}^{-2}\right)$ and biomass $\left(\mathrm{kg} \mathrm{km}^{-2}\right)$ of Helicolenus dactylopterus obtained by sector and depth-strata during the MEDITS surveys.

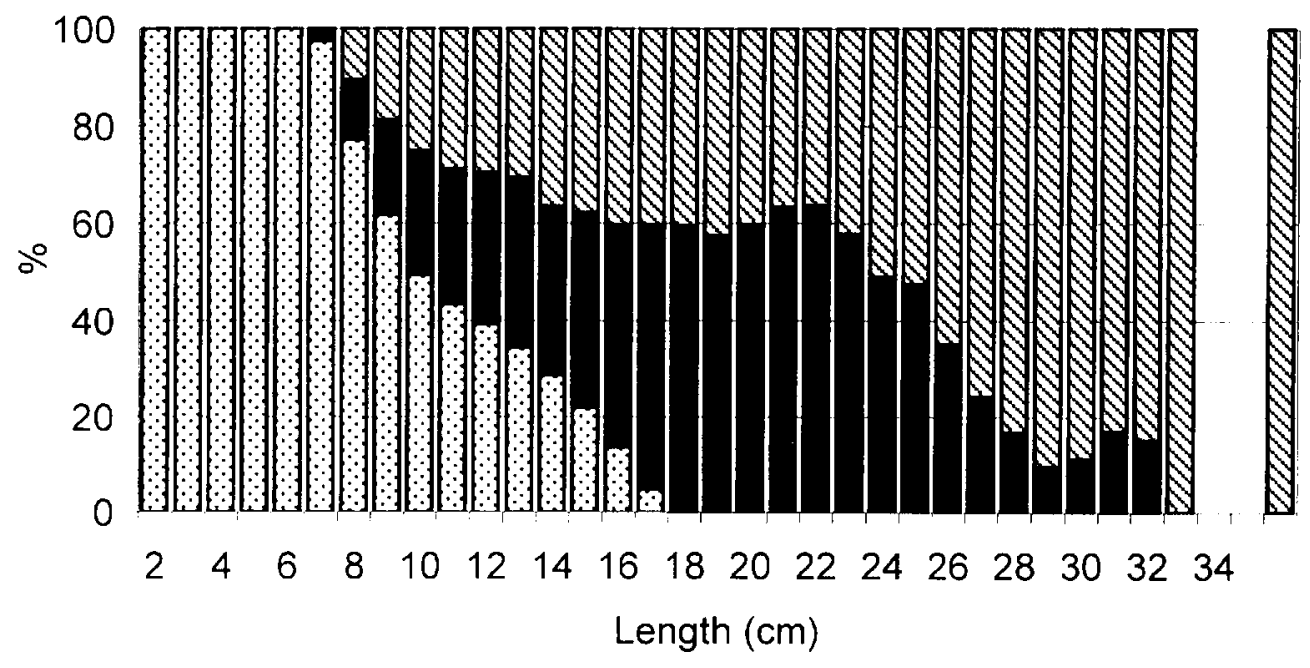

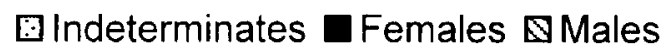

Figure 4. Proportion of females, males and indeterminates in different length-classes of Helicolenus dactylopterus, based on data from 3037 specimens. 


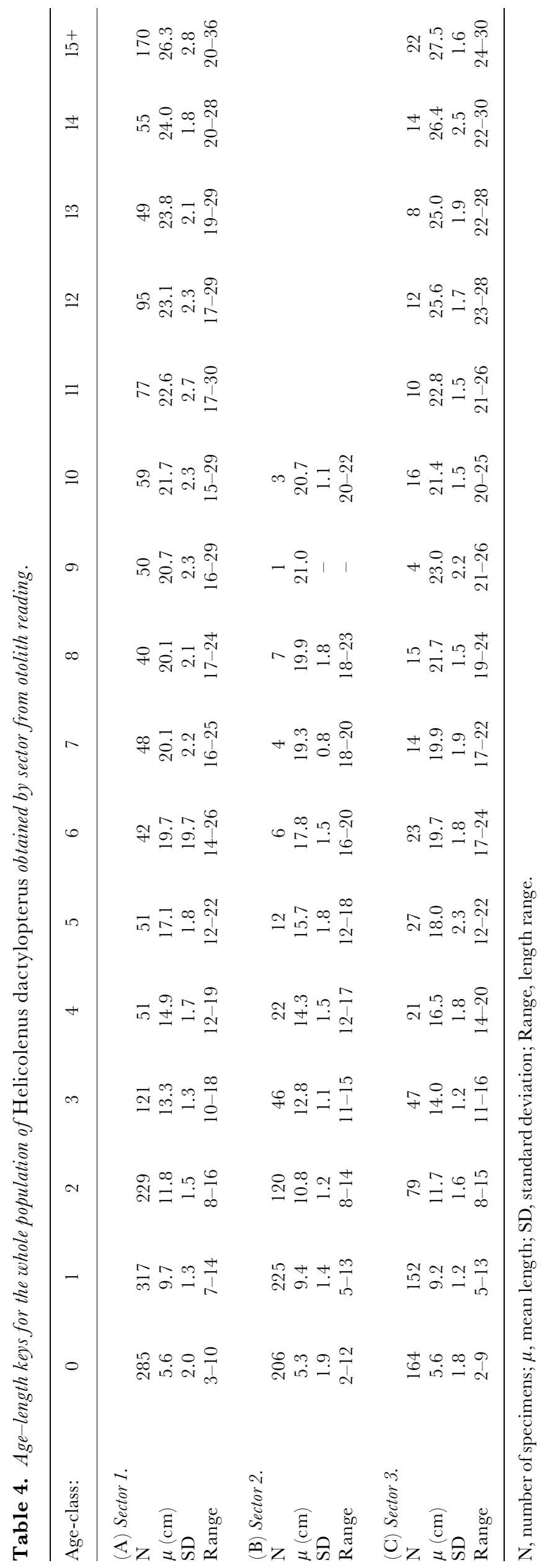



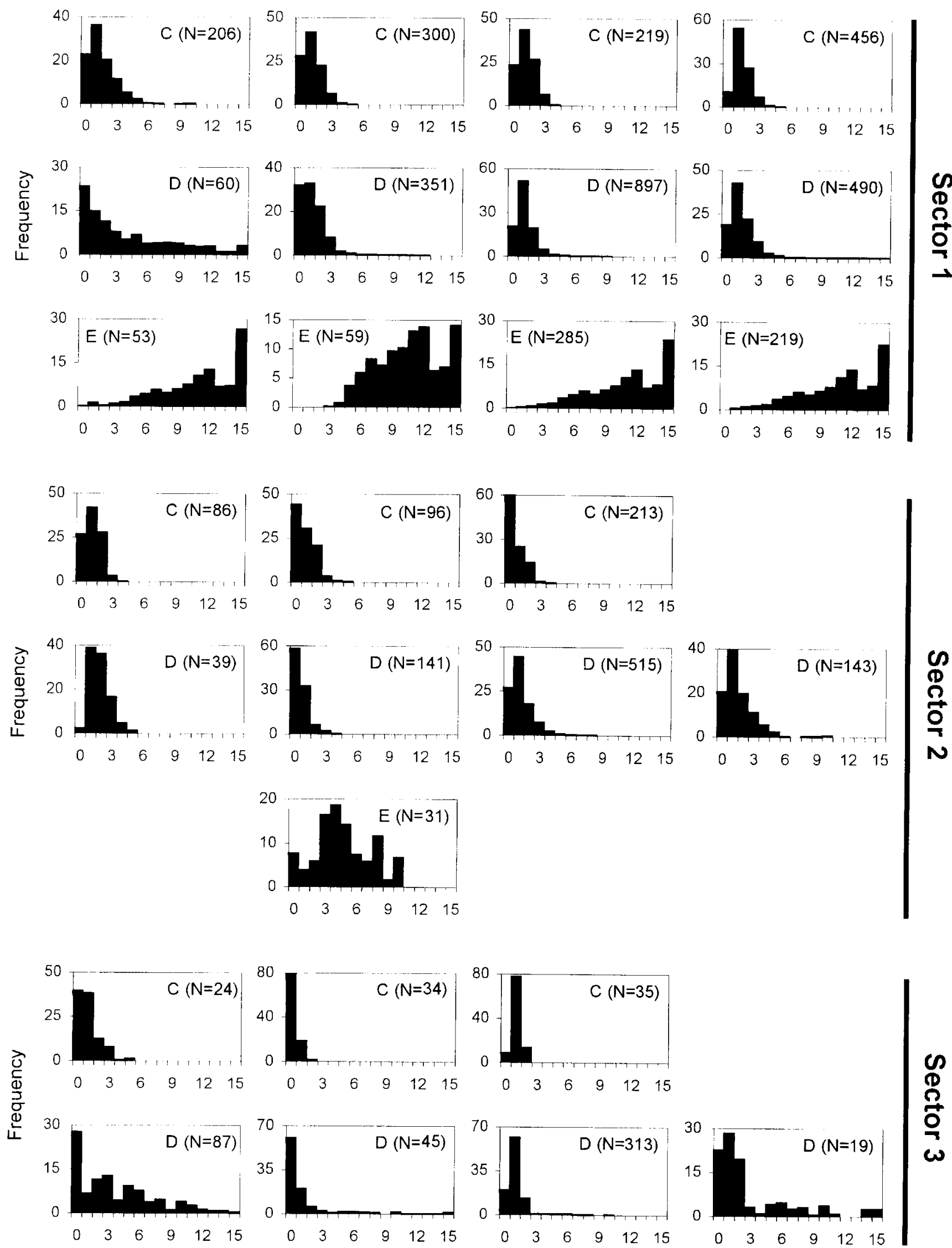

Age class $(y)$

Figure 5. Age composition of Helicolenus dactylopterus obtained by sector, depth-strata and year during the MEDITS surveys. An age class $15+$ has been grouped. 


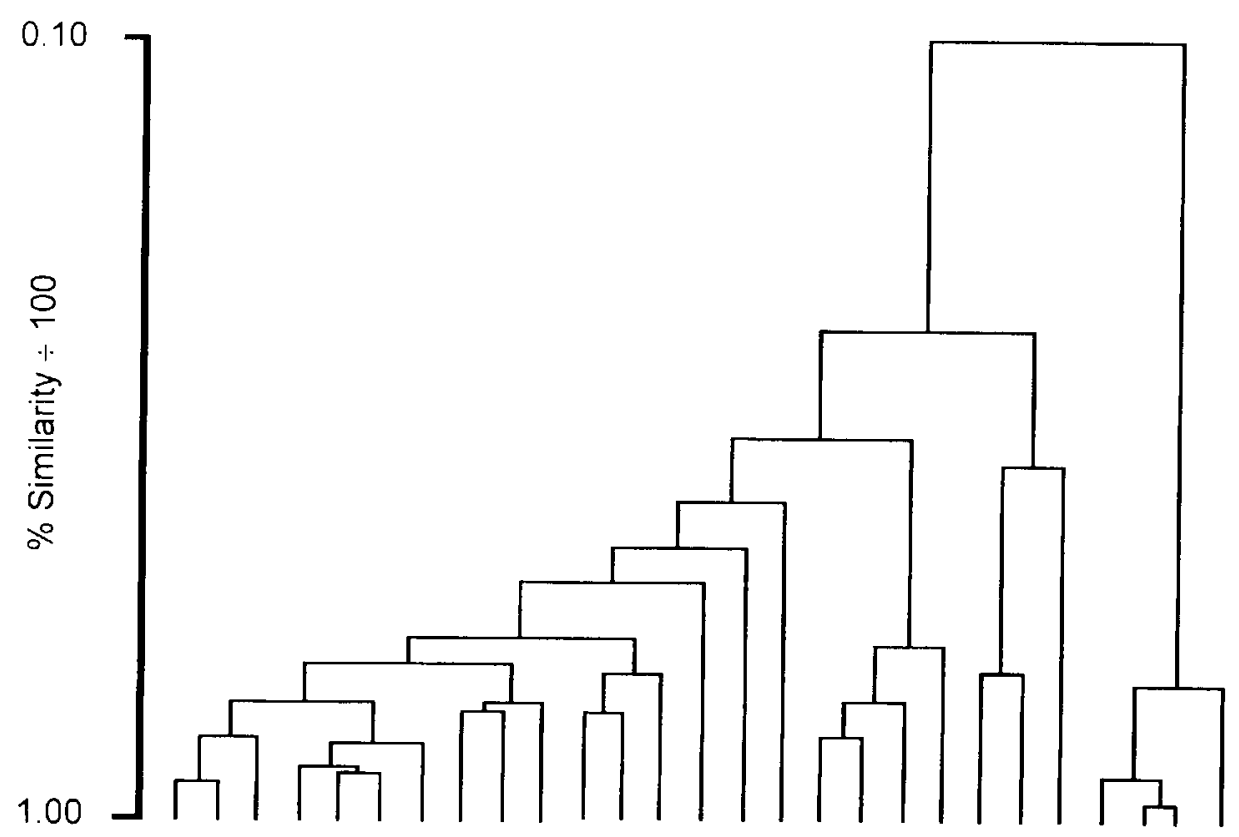

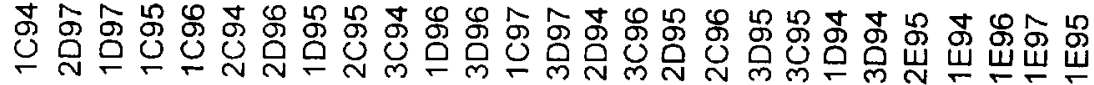

Figure 6. Dendrogram of similarity between age composition samples of Helicolenus dactylopterus obtained by sector (1, 2 and 3 ), depth-strata (A, 10-50 m; B, 51-100 m; C, 101-200 m; D, 201-500 m; E, 501-800 m) and year (1994, 1995, 1996 and 1997) in the MEDITS surveys along the western Mediterranean.

dichotomy clearly separated the samples from depthstrata $\mathrm{E}$ (between 500 and $800 \mathrm{~m}$ ) in sector 1, from the rest of the samples obtained between 100 and $800 \mathrm{~m}$ depth in sectors 2 and 3 and between 100 and $500 \mathrm{~m}$ depth in sector 1 . These separated samples from depthstrata $\mathrm{E}$ in sector 1 were composed of fish ranging $0-15 \mathrm{y}$ of age, although more than 95\% were older than $3 \mathrm{y}$. Within the rest of the samples, an additional subdivision can be discerned, and a second cluster separates samples from depth-strata D in sectors 1 and 3 on 1994 and from depth-strata E in sector 2 on 1995, which were composed of a high proportion (40-65\%) of fish older than $3 \mathrm{y}$. A third cluster separates some samples obtained on 1995 and 1996 from depth-strata C and D in sectors 2 and 3. In these samples more than $55 \%$ of fish correspond to age class 0 .

Figure 7 show the length-frequency distribution obtained between 100 and $500 \mathrm{~m}$ depth on MEDITS and MERSEL surveys in sector 1 . The dendrogram obtained from the similarity matrix among these length-frequency distributions, allowed the identification of two main groups (Figure 8). The first dichotomy of the dendrogram clearly separated the samples obtained between September and November (autumn surveys) from samples obtained between March and June (spring surveys). In autumn, a main mode around $6-8 \mathrm{~cm}$ and a secondary one between 12 and $14 \mathrm{~cm}$ could be distinguished. Within the spring surveys group, in which two large modes can be observed at around $3-5 \mathrm{~cm}$ and 9-11 cm, a second cluster separates samples obtained on June in 1991 and 1993. These surveys showed a first large mode at 5-6 cm, composed of 40 and $50 \%$ of the fish, respectively. In the rest of the spring surveys, the mode corresponding to the smallest fish is less frequent.

\section{DISCUSSION}

The present study reflects a pattern in the horizontal and vertical distribution of Helicolenus dactylopterus population in the western Mediterranean. In addition to the bathymetric gradient in abundance and population structure, extensively explained in deep-sea fish (e.g. Haedrich, 1997), our results show a northward gradient of these parameters along the surveyed area, which persist over the years analysed.

The species is frequent in the southern area $(\sim 65 \%$ of the analysed hauls), while it is occasionally northwards (40-50\% and $20-30 \%$ in sectors 2 and 3, respectively). The bathymetric distribution range shows the same pattern, being wider in the southern area, where its upper distribution limit is situated at shallower waters. Although data do not allow to establish the lowest bathymetric limit, the information available in the north-western Mediterranean suggest that the species can be considered absent below $800 \mathrm{~m}$ depth (e.g. Stefanescu et al., 1992). The depth range with the maximum frequency of occurrence is also wider in the southern area than northwards, and similar trends have been observed also in terms of abundance and biomass, with the highest and lowest indices in the southern and northern areas, respectively. Along the bathymetric range, these parameters show the greatest values between 100 and $500 \mathrm{~m}$ depth for the whole surveyed area, except in the southern area, in which biomass reach its maximum at 500-800 $\mathrm{m}$ depth. 

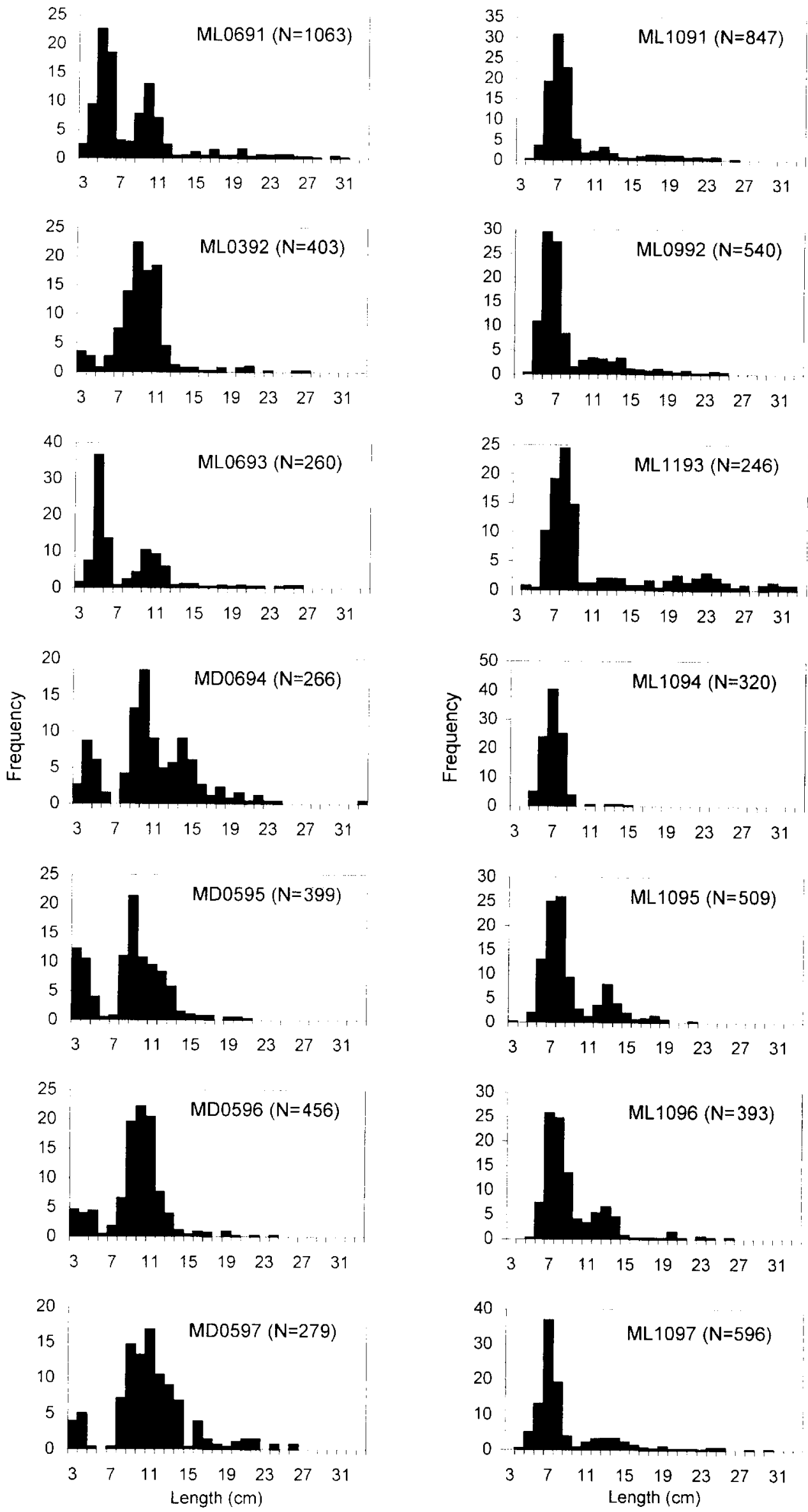

Figure 7. Length-frequency distribution of Helicolenus dactylopterus, obtained on each seasonal survey (ML, MERSEL; MD, MEDITS), developed during spring and autumn in sector 1 . 


\subsection{7}
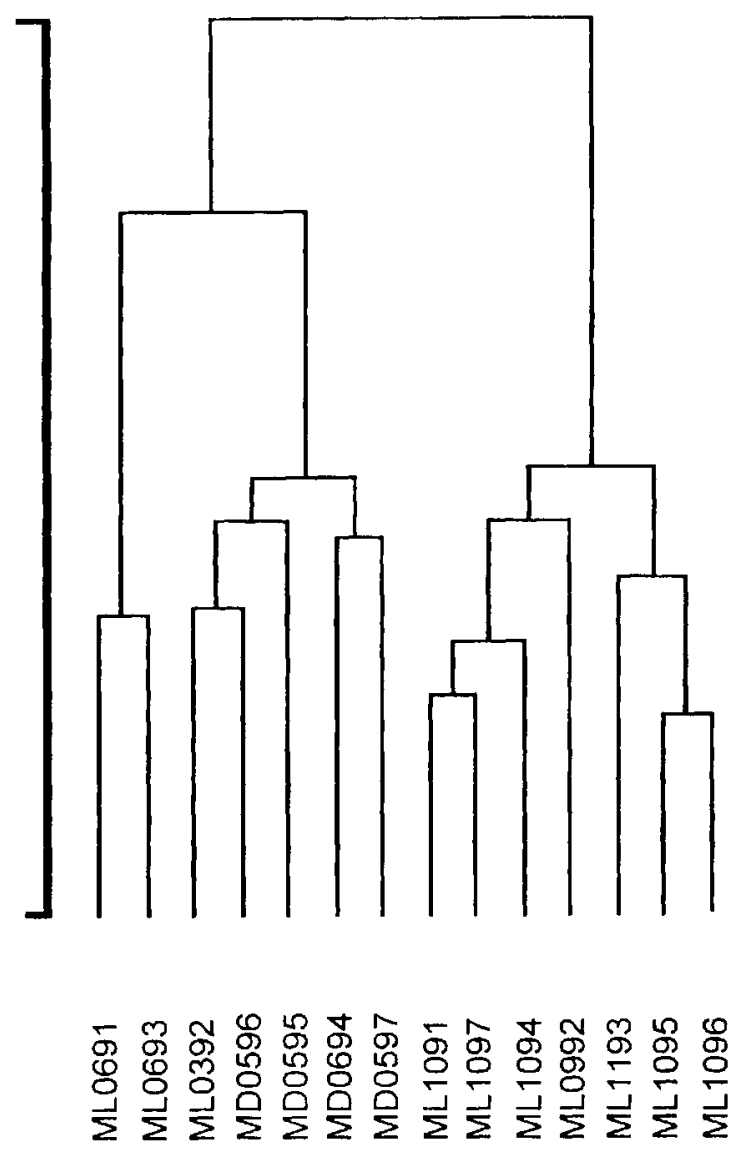

Figure 8. Dendrogram of similarity between lengthfrequency samples of Helicolenus dactylopterus obtained between 100 and $500 \mathrm{~m}$ depth at different seasonal surveys (ML, MERSEL; MD, MEDITS), developed from 1991 to 1997 during spring and autumn in sector 1 .

The age composition of the catches showed that the population consists mainly of young of the year and juvenile fish. This fraction of the population is well represented, at a mesoscale, along the whole surveyed area, but adults are well represented only at a local scale, at the deepest strata surveyed in the southern area. In this case, smaller sized individuals were concentrated at the shallowest depths within the range occupied by the species, and larger individuals only appeared below certain depths. Thus, recruits of age 0 and juveniles up to 4 -y old were restricted to depths shallower than $500 \mathrm{~m}$, while adult fish older than 6 y of age appeared below this depth. The widest size range of the species was distributed between 200 and $500 \mathrm{~m}$ depth, where specimens of all ages were caught.

The observed gradient in the population structure and distribution patterns of $H$. dactylopterus along the western Mediterranean, related to bathymetric and latitudinal trends, can be explained by a variety of direct and indirect factors of biogeographic, environmental, and anthropogenic origin.

In relation to depth, the maximum abundance at 200-500 m could be related to the major availability of food resources at this level. These bottoms are characterized by the presence, in some cases with high densities, of the middle-sized decapod crustaceans Alpheus glaber, Calocaris macandreae and Goneplax rhomboides (Cartes et al., 1994), the most important prey for H. dactylopterus (Macpherson, 1979). The different population structure observed along the bathymetric gradient of the southern area, can be explained by an ontogenic migration of the species, a phenomenon common for other deep-sea fish in the Mediterranean (Macpherson \& Duarte, 1991), which has also been reported for $H$. dactylopterus in the Ionian Sea (D'Onghia et al., 1992). In Atlantic waters, a similar bathymetric trend in abundance, biomass and mean size has been obtained off Portugal, where Cardador \& Pestana (1995) and Figueiredo et al. (1995) reported maximum abundance and biggest size for this species at 200-500 and 500-750 $\mathrm{m}$ depth, respectively. However, in this so-called 'bigger-deeper' phenomenon, a sampling artefact arising from avoidance of small trawls by large specimens at shallower depths might be considered (Merrett et al., 1991).

As latitudinal factors, firstly we can consider the relation between species abundance and geographic distribution, with a tendency of the species to become rarer towards their distribution limits (e.g. Macpherson, 1989). In this sense, $H$. dactylopterus can be considered as an Atlantic species. According to estimations of abundance in different regions of the eastern Atlantic basin, its distribution centre could be situated off the central western coast of Africa, where it has been reported maximum densities of 17,000 fish $\mathrm{km}^{-2}$ (Merret \& Marshall, 1981), while its abundance decreases progressively northwards and southwards, with average values of 88-240 fish $\mathrm{km}^{-2}$ off Portugal (Cardador \& Pestana, 1995), 8-35 fish km ${ }^{-2}$ in the Cantabrian Sea (Sánchez, 1993), 93 and 139 fish $\mathrm{km}^{-2}$ in Porcupine Seabight and Rockall Trough, respectively (J.D.M. Gordon, personal communication) and 1060 fish $\mathrm{km}^{-2}$ in Namibia (Gordoa \& Duarte, 1992). In the Mediterranean, our results have also shown this latitudinal gradient, with a clear decrease in abundance from the Strait of Gibraltar northwards.

The major Atlantic influence in the southern area surveyed is due not only to an obvious geographic factor, but also to the oceanographic conditions along the western Mediterranean (EUROMODEL Group, 1995). Several well-defined areas can be found: the southwestern basin (sector 1), the north-western basin (sector 3) and the transition zone (sector 2), in which the sills in the arch of the Balearic Islands can facilitate the contact or separation between the Atlantic and the Mediterranean populations (Massutí et al., 2000). Moreover, these abiotic factors have biological implications by affecting the primary production in pelagic waters, and subsequently the food availability in the continental slope ecosystems. In this sense, the inflow of surface Atlantic water to the Mediterranean and the outflow of deep Mediterranean water to the Atlantic through the Strait of Gibraltar is particularly relevant. Thus, the Alboran Sea can be considered an area of high productivity (similar to adjacent Atlantic waters) within the general oligotrophic context of the Mediterranean Sea. By contrast, high productivity in the north-western basin is restricted to winter periods of deep water formation and biologically active locations related to frontal boundary regions and submarine canyons. These geomorphologic structures 
have been proved to be areas of high productivity which can act as recruiting grounds (Stefanescu et al., 1994).

The high abundance indices obtained in the southern area, and especially the age composition of the population, with the constant presence of adult fish at the deepest strata surveyed, may be explained by the relatively low levels of fishing effort applied at these bottoms along the Alboran Sea. Although direct estimations of fishing effort are not available, the instantaneous fishing mortality rates $(\mathrm{F})$, calculated from length-frequency distributions in each sector and the maximum age observed by using the ELEFAN programme (Gayanillo et al., 1988) shows in sectors 2 and $3(\mathrm{~F}=0.3-0.6)$ a fishing pressure higher than in sector $1(F=0.1)$. Since Gil de Sola (1993), deep-water fisheries in the Alboran Sea are restricted to the Alboran Island, Gulf of Vera and some submarine canyons around Cape of Gata, while the open slopes of the western Alboran Sea remain unexploited bellow $500 \mathrm{~m}$ depth. Probably this fact allows the existence in the area of a well-developed spawning stock of $H$. dactylopterus, which could renew annually the exploited portion of the stock, sustaining the recruitment under conditions of high fishing mortality on the immature age groups. It is the spawning refugia paradigm, which has been hypothesized in the Mediterranean (Caddy, 1993). In areas north of the Alboran Sea, where this high fishing pressure is applied along the whole bathymetric distribution range of $H$. dactylopterus, older fish are poorly represented on trawling grounds. For this reason, in these areas the spawning stock could be reduced, and composed mainly of larger sized fish located on untrawlable bottoms. This is supported by long-line catches of big fish on rocky bottoms, both in the Mediterranean (e.g. Romanelli et al., 1997) and Atlantic waters (e.g. White et al., 1998).

Finally, the seasonality is another factor affecting the population structure of the species. In our study, clear seasonal changes are observed in the population structure of $H$. dactylopterus from the southern surveyed area. Small fish $(3-6 \mathrm{~cm})$ appear in spring, as a consequence of the species recruitment to the bottom. This recruitment extends from March, when the recruits mode is not well defined, to June, in which appear a clear mode of recruits. The modal progression, observed by comparing lengthfrequency distributions on spring and autumn suggest a growth from $4-5 \mathrm{~cm}$ in June to $7-8 \mathrm{~cm}$ in October and to $10-11 \mathrm{~cm}$ in June of the following year. These observations agree with those made by Heessen et al. (1996), which reported modes at 5 and $7 \mathrm{~cm}$ in the first and second quarters of the same year, respectively, and another mode at $9-10 \mathrm{~cm}$ in the first quarter of the following year. Similar results have also been reported in Boutière (1958), which reported modes at 6-7 and $14 \mathrm{~cm}$ in June-July.

This paper is a result of the following Spanish and European Projects: RETRO (MAR90-757), ZONAP (PB90-0166), MERSEL (IEO-213), MEDITS (DGXIV/IEO/054) and DeepSea Fisheries (DGXIV/FAIR/96/06-55). We are most grateful to all the participants in the cruises as well as the captains and crew of RVs 'Cornide de Saavedra', 'Francisco de Paula Navarro' and 'Garcia del Cid' for their help during the sampling, and Dr G. Rodgers for help with improving the English.

\section{REFERENCES}

Bertrand, J.A., Gil de Sola, L., Papaconstantinou, G., Relini, G. \& Souplet, A., 1998. An international bottom trawl survey in the Mediterranean: the MEDITS programme. Ifremer Actes de Colloques, 26, 76-93.

Boutière, H., 1958. Les scorpaenidés des eaux marocaines. Travaux de I'Institut Scientifique Chérifien, Serie Zoologique, 15, 1-83.

Caddy, J.F., 1993. Some future perspectives for assessment and management of Mediterranean fisheries. Scientia Marina, 57, 121-130.

Cardador, F. \& Pestana, G., 1995. Abundance and distribution pattern of rockfish (Helicolenus dactylopterus) in the Portuguese continental waters (ICES, Div. IXa). International Council for the Exploration of the Sea (CM Papers and Reports), CM 1995/G:19, $22 \mathrm{p}$.

Cartes, J.E., Sorbe, J.G. \& Sardà, F., 1994. Spatial distribution of deep-sea decapods and euphausiids near the bottom in the northwestern Mediterranean. Fournal of Experimental Marine Biology and Ecology, 179, 131-144.

D’Onghia, G., Matarrese, A. \& Tursi, A., 1992. Biologia di Helicolenus dactylopterus (Delaroche 1809): distribuzione de accrescimiento sui fondi batiali del mar Jonio. Oebalia, 17, (Suppl.), 129-131.

EUROMODEL Group, 1995. Progress from 1989 to 1992 in understanding the circulation of the western Mediterranean. Oceanologica Acta, 18, 255-271.

Figueiredo, M.J., Figueiredo, I. \& Moura, O., 1995. Distribution, abundance and size composition of blackbelly rosefish (Helicolenus dactylopterus) and Mediterranean redfish (Hoplostethus mediterraneus) on the slope of the Portuguese south and southern west coasts. International Council for the Exploration of the Sea (CM Papers and Reports), GM 1995/G:10, 38 p.

Gayanillo, F.C. Jr, Soriano, M. \& Pauly, D., 1989. A draft guide to the Complete ELEFAN. ICLARM Sofware Project, no. 2, 170 pp.

Gil de Sola, L., 1993. Las pesquerías del mar de Alborán (Surmediterráneo ibérico). Evolución en los últimos decenios. Informes Técnicos Instituto Español de Oceanografía, 142, 1-179.

Gil de Sola, L., 1994. Ictiofauna demersal de la plataforma continental del mar de Alborán (Mediterráneo suroccidental ibérico). Boletín Instituto Español de Oceanografía, 10, 63-79.

Gordoa, A. \& Duarte, C.M., 1992. Size-dependent density of the demersal fish off Namibia: patterns within and among species. Canadian Fournal of Fisheries and Aquatic Sciences, 49, 1990-1993.

Gordon, J.D.M., Merrett, N.R., Bergstad, O.A. \& Swan, S.C., 1996. A comparison of the deep-water demersal fish assemblages of the Rockall Trough and Porcupine Seabight, eastern North Atlantic: continental slope to rise. Fournal of Fish Biology, 49, (supplement A), 217-238.

Haedrich, R.L., 1997. Distribution and population ecology. In Deep-sea fishes (ed. D.J. Randall and A.P. Farrell), pp. 79-106. San Diego, California: Academic Press.

Heessen, H.J.L., Hislop, J.R.G. \& Boon, T.W., 1996. An invasion of the North Sea by blue-mouth, Helicolenus dactylopterus (Pisces, Scorpaenidae). ICES Journal of Marine Science, 53, 874-877.

Kelly, C.J., Connolly, P.L. \& Bracken, J.J., 1999. Age estimation, growth, maturity, and distribution of the bluemouth rockfish Helicolenus d. dactylopterus (Delaroche 1809) from the Rockall Trough. ICES Fournal of Marine Science, 56, $61-74$.

Macpherson, E., 1979. Estudio sobre el régimen alimentario de algunos peces en el Mediterráneo occidental. Miscel.lània Zoològica, 5, 93-107.

Macpherson, E., 1989. Influence of geographical distribution, body size and diet on population density of benthic fishes off Namibia (South West Africa). Marine Ecology Progress Series, 50, 295-299. 
Macpherson, E. \& Duarte, C.M., 1991. Bathymetric trends in demersal fish size: is there a general relationship? Marine Ecology Progress Series, 71, 103-112.

Macpherson, E. \& Duarte, C.M., 1994. Patterns in species richness, size, and latitudinal range of East Atlantic fishes. Ecography, 17, 242-248.

Macpherson, E. \& Gordoa, A., 1996. Biomass spectra in benthic fish assemblages in the Benguela System. Marine Ecology Progress Series, 138, 27-32.

Massutí, E., Morales-Nin, B. \& Moranta, J., 2000. Age and growth of blue-mouth, Helicolenus dactylopterus (Osteichthyes: Scorpaenidae), in the western Mediterranean. Fisheries Research, 46, 165-176.

Merrett, N.R., Haedrich, R.L., Gordon, J.D.M. \& Stehmann, M., 1991. Deep demersal fish assemblage structure in the Porcupine Seabight (eastern North Atlantic): results of single warp trawling at lower slope to abyssal soundings. Fournal of the Marine Biological Association of the United Kingdom, 71, 359-373.

Merret, N.R. \& Marshall, N.B., 1981. Observations on the ecology of deep-sea bottom-living fishes collected off northwest Africa $\left(08^{\circ}-27^{\circ} \mathrm{N}\right)$. Progress in Oceanography, 9, 185-244.

Muñoz, M., Casadevall, M. \& Bonet, S., 1999. Annual reproductive cycle of Helicolenus dactylopterus (Telostei: Scorpaeniformes) with special reference to the ovaries sperm storage. Fournal of the Marine Biological Association of the United Kingdom, 79, 521-529.
Romanelli, M., Palladino, S., Tarulli, E. \& Ferretti, M., 1997. Stima dell'accrescimento di Helicolenus d. dactylopterus (Delaroche) in Adriatico Meridionale tramite esame dell sagittae di esemplari prelevati con reti a strascico e palangari di fondo. Biologia Marina Mediterrania, 4, 554-556.

Sánchez, F., 1993. Las comunidades de peces de la plataforma del Cantábrico. Publicaciones Especiales Instituto Español de Oceanografía, 13, 1-137.

Sardà, F., Cartes, J.E., Company, J.B. \& Albiol, A., 1998. A modified commercial trawl used to sample deep-sea megabenthos. Fisheries Science, 64, 492-493.

Stefanescu, C., Lloris, D. \& Rucabado, J., 1992a. Deep-living demersal fishes in the Catalan Sea (western Mediterranean) below a depth of 1000 m. Fournal of Natural History, 26, 197-213.

Stefanescu, C., Morales-Nin, B. \& Massutí, E., 1994. Fish assemblages on the slope in the Catalan Sea (western Mediterranean): influence of a submarine canyon. Fournal of the Marine Biological Association of the United Kingdom, 74, $499-512$.

White, D.B., Wyanski, D.M. \& Sedberry, G.R., 1998. Age, growth, and reproductive biology of the blackbelly rosefish from the Carolinas, U.S.A. Fournal of Fish Biology, 53, 1274-1291.

Submitted 12 June 2000. Accepted 11 September 2000. 